\title{
Front Matter: Volume 7877
}

, "Front Matter: Volume 7877," Proc. SPIE 7877, Image Processing: Machine Vision Applications IV, 787701 (14 March 2011); doi: 10.1117/12.890194

Event: IS\&T/SPIE Electronic Imaging, 2011, San Francisco Airport, California, SPIE. United States 


\title{
PROCEEDINGS OF SPIE
}

\section{Image Processing: Machine Vision Applications IV}

\author{
David Fofi \\ Philip R. Bingham \\ Editors
}

25-27 January 2011

San Francisco, California, United States

Sponsored and Published by

IS\&T-The Society for Imaging Science and Technology

SPIE

Volume 7877 
The papers included in this volume were part of the technical conference cited on the cover and title page. Papers were selected and subject to review by the editors and conference program committee. Some conference presentations may not be available for publication. The papers published in these proceedings reflect the work and thoughts of the authors and are published herein as submitted. The publishers are not responsible for the validity of the information or for any outcomes resulting from reliance thereon.

Please use the following format to cite material from this book:

Author(s), "Title of Paper," in Image Processing: Machine Vision Applications IV, edited by

David Fofi, Philip R. Bingham, Proceedings of SPIE Vol. 7877 (SPIE, Bellingham, WA, 2011) Article CID Number.

ISSN 0277-786X

ISBN 9780819484147

Copublished by

SPIE

P.O. Box 10, Bellingham, Washington 98227-0010 USA

Telephone +1 3606763290 (Pacific Time) · Fax +1 3606471445

SPIE.org

and

IS\&T-The Society for Imaging Science and Technology

7003 Kilworth Lane, Springfield, Virginia, 22151 USA

Telephone +1 7036429090 (Eastern Time) · Fax +1 7036429094

imaging.org

Copyright (C) 2011, Society of Photo-Optical Instrumentation Engineers and The Society for Imaging Science and Technology.

Copying of material in this book for internal or personal use, or for the internal or personal use of specific clients, beyond the fair use provisions granted by the U.S. Copyright Law is authorized by the publishers subject to payment of copying fees. The Transactional Reporting Service base fee for this volume is $\$ 18.00$ per article (or portion thereof), which should be paid directly to the Copyright Clearance Center (CCC), 222 Rosewood Drive, Danvers, MA 01923. Payment may also be made electronically through CCC Online at copyright.com. Other copying for republication, resale, advertising or promotion, or any form of systematic or multiple reproduction of any material in this book is prohibited except with permission in writing from the publisher. The CCC fee code is $0277-786 \mathrm{X} / 11 / \$ 18.00$.

Printed in the United States of America.

Paper Numbering: Proceedings of SPIE follow an e-First publication model, with papers published first online and then in print and on CD-ROM. Papers are published as they are submitted and meet publication criteria. A unique, consistent, permanent citation identifier (CID) number is assigned to each article at the time of the first publication. Utilization of CIDs allows articles to be fully citable as soon they are published online, and connects the same identifier to all online, print, and electronic versions of the publication. SPIE uses a six-digit CID article numbering system in which:

- The first four digits correspond to the SPIE volume number.

- The last two digits indicate publication order within the volume using a Base 36 numbering system employing both numerals and letters. These two-number sets start with 00, 01, 02, 03, 04, 05, 06, 07, $08,09,0 \mathrm{~A}, \mathrm{OB} \ldots \mathrm{OZ}$, followed by 10-1Z, 20-2Z, etc.

The CID number appears on each page of the manuscript. The complete citation is used on the first page, and an abbreviated version on subsequent pages. Numbers in the index correspond to the last two digits of the six-digit CID number. 


\section{Contents}

vii Conference Committee

IMAGE AND SIGNAL PROCESSING I

787702 Lipschitz exponents based signal restoration [7877-01]

B. Jalil, O. Beya, E. Fauvet, O. Laligant, Le2i, CNRS, Univ. de Bourgogne (France)

787703 Real-time wavelet-based inline banknote-in-bundle counting for cut-and-bundle machines [7877-02]

D. Petker, OWITA GmbH (Germany); V. Lohweg, E. Gillich, Ostwestfalen-Lippe Univ. of Applied Sciences (Germany); T. Türke, KBA-NotaSys SARL (Switzerland); H. Willeke, J. Lochmüller, KBA-Bielefeld (Germany); J. Schaede, KBA-NotaSys SARL (Switzerland)

787704 A robust segmentation and tracking method for characterizing GNSS signals reception environment [7877-03]

A. Cohen, C. Meurie, Y. Ruichek, Univ. de Technologie de Belfort-Montbéliard (France); J. Marais, Univ. Lille Nord de France (France)

IMAGE AND SIGNAL PROCESSING II

787705 Accurate, fast, and robust centre localisation for images of semiconductor components [7877-04]

F. Timm, Univ. of Lübeck (Germany) and Pattern Recognition Co. GmbH (Germany);

E. Barth, Univ. of Lübeck (Germany)

787706 A 2D histogram representation of images for pooling [7877-27]

X. YU, Y.-J. Zhang, Tsinghua Univ. (China)

787707 Gram polynomial image decimation and its application to non-rigid registration [7877-06]

A. Badshah, P. O'Leary, M. Harker, Montan Univ. Leoben (Austria)

787708 Interactive image quantification tools in nuclear material forensics [7877-07]

R. Porter, C. Ruggiero, D. Hush, N. Harvey, P. Kelly, W. Scoggins, L. Tandon, Los Alamos

National Lab. (United States)

\section{OUTDOOR VISION}

787709 Line segment based structure and motion from two views [7877-28]

S. Mosaddegh, A. Fazlollahi, D. Fofi, Le2i, CNRS, Univ. de Bourgogne (France); P. Vasseur, Univ. de Picardie Jules Verne (France)

$7877 \mathrm{OA}$ Vision based forest smoke detection using analyzing of temporal patterns of smoke and their probability models [7877-09]

S. Ham, B.-C. Ko, J.-Y. Nam, Keimyung Univ. (Korea, Republic of) 
7877 OB Estimation of fire volume by stereovision [7877-10]

T. Molinier, L. Rossi, SPE, CNRS, Univ. of Corsica (France); M. Akhloufi, Ctr. of Robotics and

Vision (Canada); Y. Tison, A. Pieri, SPE, CNRS, Univ. of Corsica (France)

7877 OC Pavement distress detection and severity analysis [7877-11]

E. Salari, G. Bao, The Univ. of Toledo (United States)

\section{FEATURES AND PATTERN RECOGNITION}

7877 OF Multi-frame decision level fusion for face classification based on a photon-counting linear discriminant analysis [7877-14]

S. Yeom, Daegu Univ. (Korea, Republic of)

7877 OG Pose-robust face recognition using shape-adapted texture features [7877-15]

T. Gernoth, A. Gooßen, R.-R. Grigat, Technische Univ. Hamburg-Harburg (Germany)

\section{MEDICAL IMAGING}

$7877 \mathrm{OH} \quad$ A novel framework for white blood cell segmentation based on stepwise rules and morphological features [7877-16]

J.-W. Gim, J. Park, J.-H. Lee, B. Ko, J.-Y. Nam, Keimyung Univ. (Korea, Republic of)

7877 Ol Image fusion on redundant lifting non-separable wavelet transforms [7877-17]

W. Wang, Chang'an Univ. (China); J. Zeng, Univ. of Electronic Science and Technology of China (China); S. Yin, X. Wang, Chang'an Univ. (China)

\section{MACHINE VISION AND INDUSTRIAL APPLICATIONS I}

7877 0J Non-parametric texture defect detection using Weibull features [7877-18]

F. Timm, Univ. of Lübeck (Germany) and Pattern Recognition Co. GmbH (Germany);

E. Barth, Univ. of Lübeck (Germany)

7877 OL Quantitative measurement by artificial vision of small bubbles in flowing mercury [7877-25]

V. C. Paquit, M. W. Wendel, D. K. Felde, B. W. Riemer, Oak Ridge National Lab. (United States)

\section{MACHINE VISION AND INDUSTRIAL APPLICATIONS II}

7877 OM Coded source neutron imaging [7877-21]

P. Bingham, H. Santos-Villalobos, K. Tobin, Oak Ridge National Lab. (United States)

$7877 \mathrm{ON}$ Towards autonomic computing in machine vision applications: techniques and strategies for in-line 3D reconstruction in harsh industrial environments [7877-22]

J. Molleda, R. Usamentiaga, D. F. García, F. G. Bulnes, Univ. of Oviedo (Spain) 
$787700 \quad$ Evaluating distances using a coded lens camera and a blur metric [7877-23]

L. J. Angot, C.-C. Chang, Y.-L. Chen, Industrial Technology Research Institute (Taiwan)

7877 OP Automatic firearm class identification from cartridge cases [7877-24]

S. Kamalakannan, Texas Tech Univ. (United States); C. J. Mann, P. R. Bingham,

T. P. Karnowski, S. S. Gleason, Oak Ridge National Lab. (United States)

\section{INTERACTIVE PAPER SESSION}

7877 OU Segmentation and visualization of anatomical structures from volumetric medical images [7877-31]

J. Park, S. Park, Mokpo National Univ. (Korea, Republic of); W. Cho, S. Kim, G. Kim, G. Ahn, M. Lee, J. Lim, Chonnam National Univ. (Korea, Republic of)

7877 OV Extraction and fusion of spectral parameters for face recognition [7877-32]

B. Boisier, B. Billiot, Z. Abdessalem, P. Gouton, Univ. de Bourgogne (France); J. Y. Hardeberg, Gjøvik Univ. College (France)

7877 OW Monitoring plant growth using high resolution micro-CT images [7877-33]

V. C. Paquit, S. S. Gleason, U. C. Kalluri, Oak Ridge National Lab. (United States)

7877 OX Automating the estimation of coating thickness measurements in the ball crater technique [7877-35]

J. G. Huang, City Univ. London (United Kingdom) and Teer Coatings Ltd. (United Kingdom); P. Liatsis, City Univ. London (United Kingdom); K. Cooke, D. Teer, Teer Coatings Ltd. (United Kingdom)

Author Index 
Downloaded From: https://www.spiedigitallibrary.org/conference-proceedings-of-spie on 26 Apr 2023

Terms of Use: https://www.spiedigitallibrary.org/terms-of-use 


\title{
Conference Committee
}

\author{
Symposium Chair \\ Sabine Süsstrunk, École Polytechnique Fédérale de Lausanne \\ (Switzerland) \\ Symposium Cochair
}

Majid Rabbani, Eastman Kodak Company (United States)

Conference Chairs

David Fofi, Université de Bourgogne (France)

Philip R. Bingham, Oak Ridge National Laboratory (United States)

Program Committee

Atilla M. Baskurt, Université Claude Bernard Lyon 1 (France)

Pierrick T. Bourgeat, Australian e-Health Research Center (Australia)

Jun Cheng, Chinese Academy of Sciences (China)

Michael J. Cree, The University of Waikato (New Zealand)

Laurent C. Duval, IFP (France)

Ewald Fauster, vatron GmbH (Austria)

Steven P. Floeder, 3M Company (United States)

Luciano F. Fontoura Da Costa, Universidade de São Paulo (Brazil)

Olivier Laligant, Université de Bourgogne (France)

Edmund Lam, The University of Hong Kong (Hong Kong, China)

Xavier Lladó, Universitat de Girona (Spain)

Fabrice Mériaudeau, Université de Bourgogne (France)

Dinesh Nair, National Instruments Corporation (United States)

Kurt S. Niel, Fachhochschule Wels (Austria)

Jeffery R. Price, Oak Ridge National Laboratory (United States)

A. Ravishankar Rao, IBM Thomas J. Watson Research Center (United States)

Hamed Sari-Sarraf, Texas Tech University (United States)

Peter Schelkens, Vrije Universiteit Brussel (Belgium)

Ralph Seulin, Université de Bourgogne (France)

Ivan W. Selesnick, Polytechnic Institute of New York University

(United States)

Yvon Voisin, Université de Bourgogne (France)

Gerald Zauner, Fachhochschule Wels (Austria) 


\author{
Session Chairs \\ $1 \quad$ Image and Signal Processing I \\ Philip R. Bingham, Oak Ridge National Laboratory (United States) \\ 2 Image and Signal Processing II \\ Philip R. Bingham, Oak Ridge National Laboratory (United States) \\ 3 Outdoor Vision \\ Bushra Jalil, Université de Bourgogne (France) \\ 4 Features and Pattern Recognition \\ Saleh Mosaddegh, Université de Bourgogne (France) \\ $5 \quad$ Medical Imaging \\ Bushra Jalil, Université de Bourgogne (France) \\ 6 Machine Vision and Industrial Applications I \\ Philip R. Bingham, Oak Ridge National Laboratory (United States) \\ 7 Machine Vision and Industrial Applications II \\ Saleh Mosaddegh, Université de Bourgogne (France)
}

